\title{
頭頸部癌の癌性疼痛に対するケタミンの持続皮下注入法について
}

\author{
鄭漢忠・野谷健一・戸塚靖則・福田博 \\ 大島英治*
}

\section{Continuous subcutaneous ketamine infusion for the pain in patients with head and neck cancer}

\author{
Kanchū TeI - Ken-ichi Notani • Yasunori Totsuka \\ Hiroshi Fukuda - Eiji Ōshima*
}

\begin{abstract}
Patients with oral cancer often suffer from severe pain even when their general condition is good. Therefore medication is desirable to relieve pain without disturbing consciousness.

In this study, we tried a continuous subcutaneous infusion of ketamine to relieve pain in 5 patients with head and neck cancer in the terminal stage.

The results are as follows: it was markedly effective on 2 patients and relatively effective on 2 but not effective on 1 patient. No particular side effect was observed in any case and the patients kept clear consciousness during medication.

It is suggested that this method is effective on patients in the early stage.
\end{abstract}

Key words: continuous subcutaneous ketamine infusion, pain in patients with head and neck cancer

\section{緒}

言

頭頸部領域に打ける癌性疼痛の特徵として, 疼痛域が 三叉神経, 舌咽神経などの脳神経支配であるため, 除痛 法として選択的神経ブロックが多用されている。しか し，これを行うには熟練を要すること，他の領域で頻用 されている硬膜外腔への麻薬類の投与は無効であること から，各種鎮痛剂や麻薬の全身的投与が多用されている のが現状である.

今回，われわれはケタミンの持続皮下注入法を頭頸部

北海道大学蔽学部口腔外科学第 1 講座 （主任：福田博教授）

* 財団法人田附興風会医学研究所北野病院麻醉科 (主任：浦部伸方)

First Department of Oral Surgery, School of Dentistry, Hokkaido University (Chief: Prof. Hiroshi Fukuda)

* Department of Anesthesiology, Tazuke Kōfūkai Foundation Medical Research Institute Kitano Hospital (Chief: Nobukata Urabe)

受付日：昭和61年10月27日
癌の未期患者 5 名に施行し，その鎮痛効果について検討 を行ったので報告する.

\section{対象ならびに方法}

対象は昭和 60 年 1 月から同年11月までに, 当科で入院 加療した 5 名で, 表 1 飞患者の年齢, 性, 原発疾患名, 疼痛部位, 拈よび，ヶタミン投与前の鎮痛法を示した。 ケタミン投与と鎮痛効果の判定は大島らの方法 ${ }^{11}$ を改变 して用いた。すなおち，持続注入ポンプはニプロ社製 SP-10 用い, $27 \mathrm{G}$ の翼状針を前胸部皮下へ刺入固定 し, ケタラール $50^{\circledR}$ (塩酸ケタミン $50 \mathrm{mg} / \mathrm{ml}$ ) を投与 した（写真 1，2）. 持続注入ポンプは写真 2 のようにウ エストポーチを利用し，携带可能とした。ケタミンの投 与量は $5 \mathrm{mg} /$ 時より開始し, 疼痛の程度に応じて増減し た.ケタミン以外の鎮痛剤の使用は制限せず，患者の希 望々任せて投与した。鎮痛効果の判定は，患者の自覚的 疼痛度と併用鎮痛薬の使用量に基づく他覚的疼痛度に因 った. 自覚的疼痛度の判定は表 2 のよな患者への直接 質問によって行った，疼痛度を 4 段階とし，1 日を0〜 8，8～16，16〜24時に区分し，おのおのの時間帯におけ る最大疼痛度を記録した。これは，設定された時間内 
表 15 例の年路, 性別, 疾患名, 疼痛部位, ケタミン開始前の除痛法

\begin{tabular}{|c|c|c|c|c|c|}
\hline No. & 年粭 & 性別 & 垁患名 & 疼痛部位 & ケタミン開始前の除痛法 \\
\hline 1 & 66 & 男 & $\begin{array}{l}\text { 右上顎腫痬 } \\
\text { 再発 }\end{array}$ & $\begin{array}{l}\text { 右眼窩扣よび } \\
\text { 眼窝周囲 }\end{array}$ & $\begin{array}{l}\text { 上顎神経ブロック 塩酸モルフィン内服 } 20 \mathrm{mg} / \mathrm{day} \\
\text { インドメサシン坐 } 200 \mathrm{mg} / \mathrm{day} \text { ケトプロフェン } 50 \mathrm{mgIM}\end{array}$ \\
\hline 2 & 48 & 男 & 左舌腫演再発 & 左舌根, 咽頭 & $\begin{array}{l}\text { インドメサシン坐 } 200 \mathrm{mg} / \mathrm{day} \\
\text { 塩酸ヒドロキシシン } 50 \sim 100 \mathrm{mg} \text { ペンタゾシン } 15 \sim 30 \mathrm{mgIM}\end{array}$ \\
\hline 3 & 68 & 男 & $\begin{array}{l}\text { 右顎下部 } \\
\text { 尰湯再発 }\end{array}$ & $\begin{array}{l}\text { 右舌緑部おょび } \\
\text { 右下䫟〜顎下部 }\end{array}$ & $\begin{array}{l}シ ク ロ フ ェ ナ ッ ク \mathrm{Na} \text { 坐 } 100 \sim 150 \mathrm{mg} / \mathrm{day} \\
\text { Sedes } \mathrm{G} \text { 2.0〜3.0 }\end{array}$ \\
\hline 4 & 82 & 女 & $\begin{array}{l}\text { 右下顎菌肉 } \\
\text { 尰演再発 }\end{array}$ & $\begin{array}{c}\text { 右側耳下腺咬筋部 } \\
\quad \sim \text { 側頭部 }\end{array}$ & 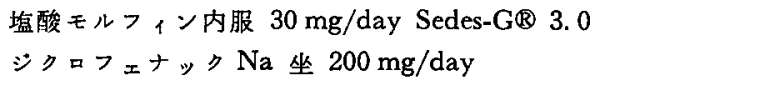 \\
\hline 5 & 51 & 男 & 右舌腫湯再発 & \begin{tabular}{|c|} 
右下影部 買下部 \\
後頸部
\end{tabular} & $\begin{array}{l}\text { ジロロェナック } \mathrm{Na} \text { 坐 } 200 \mathrm{mg} / \mathrm{day} \\
\text { ペンタゾシン } 30 \mathrm{mg} / \mathrm{dayIM} オ ヒ ゚ フ ト 100 \mathrm{mg} / \mathrm{dayIM}\end{array}$ \\
\hline
\end{tabular}

表 2

1）ケタミンの投与效果の判定法 著效：自覚的㕲よび他覚的に 疼痛の消失をみとめるもの 有効：自覚的あるいは他覚的に 疼痛の瑷解をみとめるるの

無效：自覚的に与他覚的に。 苳痛の楥解をみとめないもの

(自覚的緩解度：患者への直接質問による

他覚的緩解度：併用鎮痛薬の使用頻度, 使用量の減少等から判定

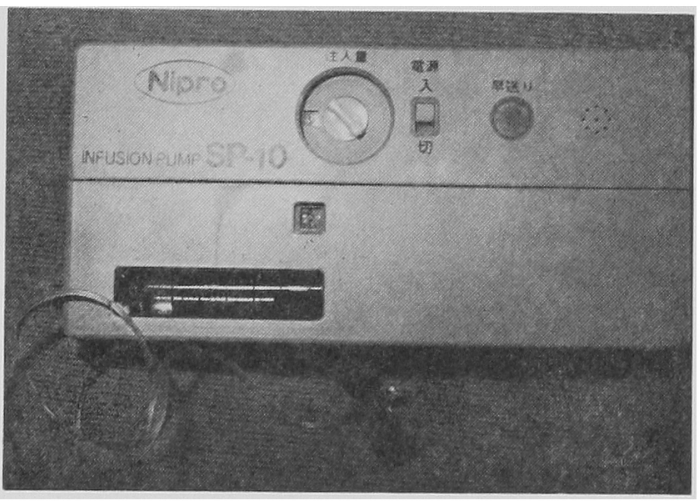

写真 1 持続注入ポンプ（ニプロ社塐 SP-10）

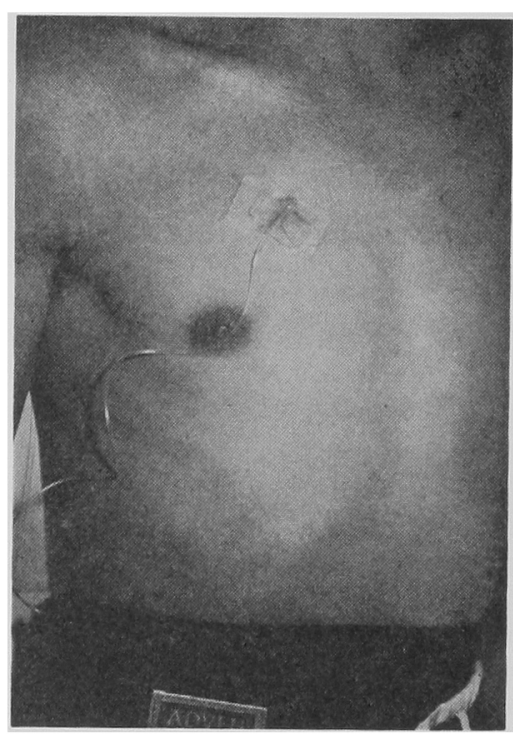

写真 2 ウストポーチ内にポンブ本 体を入れたところ 


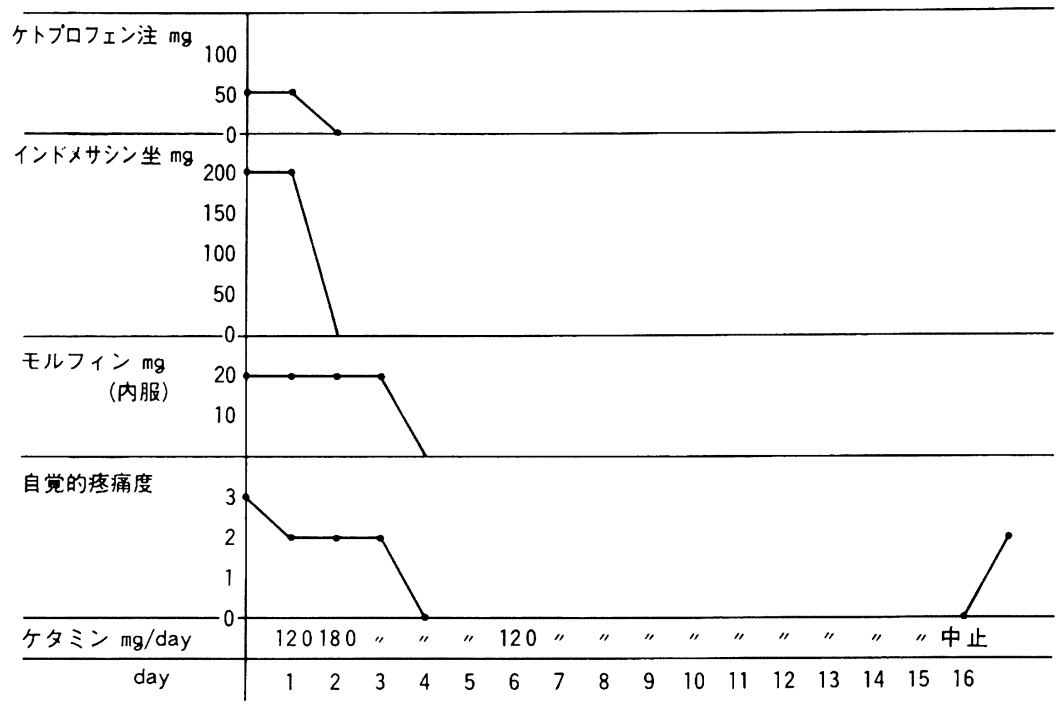

図 1 症例 1 : ケタミン使用中の併用鎮痛薬の推移および自覚的疼痛度の変化

に, 無痛状態, 種々の程度の疼痛が混在した場合, その 最大疼痛をもって疼痛度とすることにより, 鎮痛薬の過 大評価を避けるためである。

\section{結果}

症例 1 （図1）右上買畽瘍再発により頭蓋底浸潤を認 めた66歳男性で, 右眼, 眼䈑周囲の疼痛を訴えていた。 上顎神経ブロックにより疼痛は一時的に緩解したが, 腫 瘍の增大に伴って疼痛も增強され，モルフィン内服を試 みた。しかし, 悪心, 嘔吐, めまい, ふらつきが強いた め投与を中止し，ケタミン $(5 \mathrm{mg} /$ 時) 投与を開始した ところ，1 時間後には疼痛が軽減した。 2 日目より 7.5 $\mathrm{mg} /$ 時に增量したところ，4 日目には無痛が 得られ他の 鎮痛薬が不要となった，その後, 軽度の血圧上昇と心拍 数の増加を認めたため 6 日目より $5 \mathrm{mg} /$ 時に减量した. 夜間に軽度の疼痛がある程度となったが, 高血圧, 頻脈

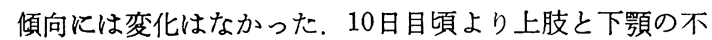
随意運動が生じ，16日目に投与を中止したところ，翌日 より持続性疼痛の出現を認めた。 ケタミンの中止後も， 高血圧, 頻脈, 不随意運動は持続した。 中止後 8 日目, 呼吸不全により永眠.

症例 2 (図 2) 舌腫瘍進展例で, 舌根, 咽頭部に激痛 を訴える48歳男性. この患者は医療に対して不信感が強 かった. $5 \mathrm{mg} /$ 時で 2 日間ヶタミンを投与したが効果な く, 3 日目より $7.5 \mathrm{mg} /$ 時に增量したところ, 疼痛は軽 减したが眠気が出現した．患者がケタミン投与に強い不 安を抱いたため投与を中止した。 中止後再度激痛が出現 した。

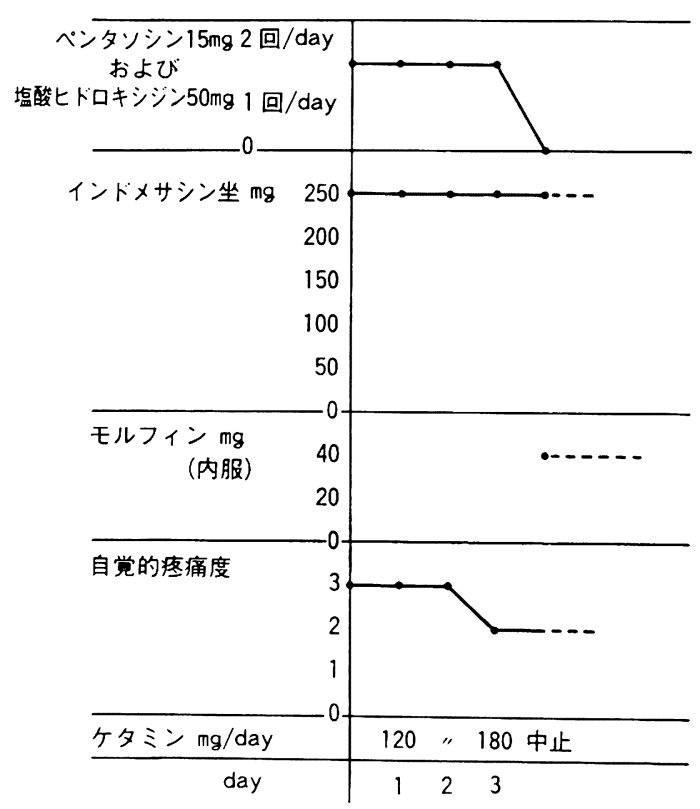

図 2 症例 2 : ケタ ン使用中の併用鎮痛薬の 推移および自覚的疼痛度の変化

症例 3 (図3) 下䫇腫瘍再発例で, 右舌縁, 䫇下部に 疼痛を訴える68歳の男性. 全身状態は比較的良好で, 日 常生活での制限は軽度であったが，1 日に $2 \sim 3$ 時間の 発作性の 激痛を認めた. $5 \mathrm{mg} /$ 時で投与を開始し， 5 日 目に無痛が得られたが，11日目外照射開始と同時に疼痛 が増強したため, $12.5 \mathrm{mg} /$ 時まで増量し疼痛度 $0 \sim 1$ の 


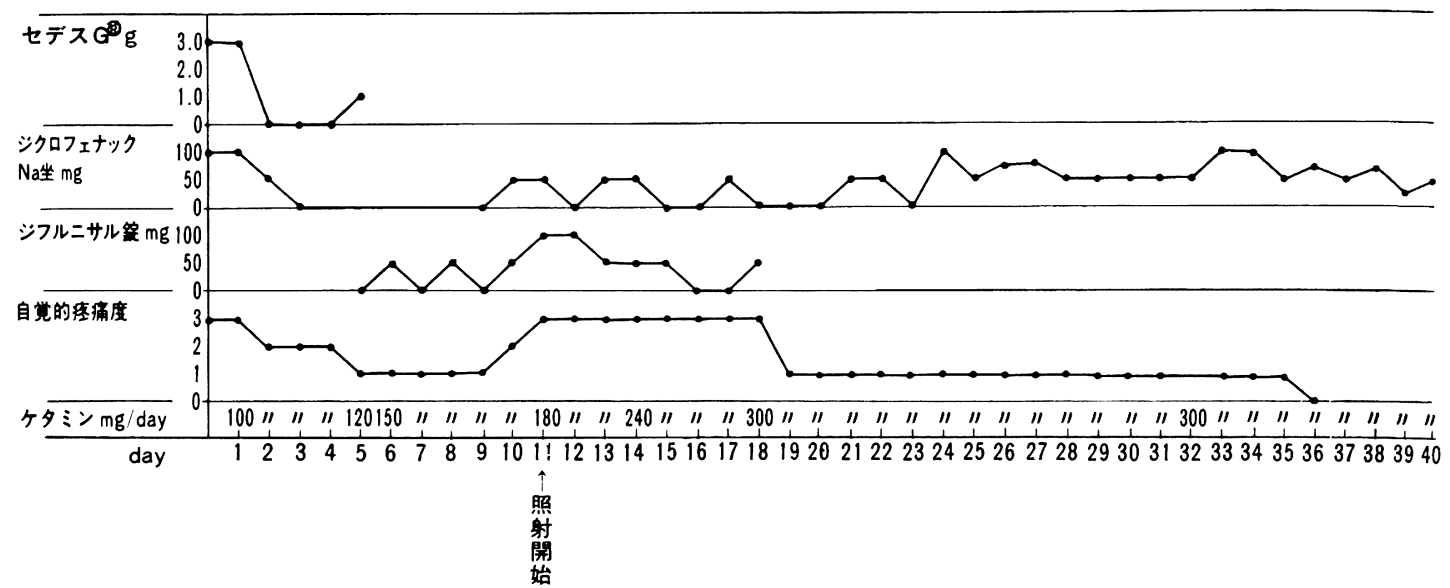

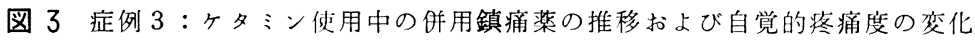

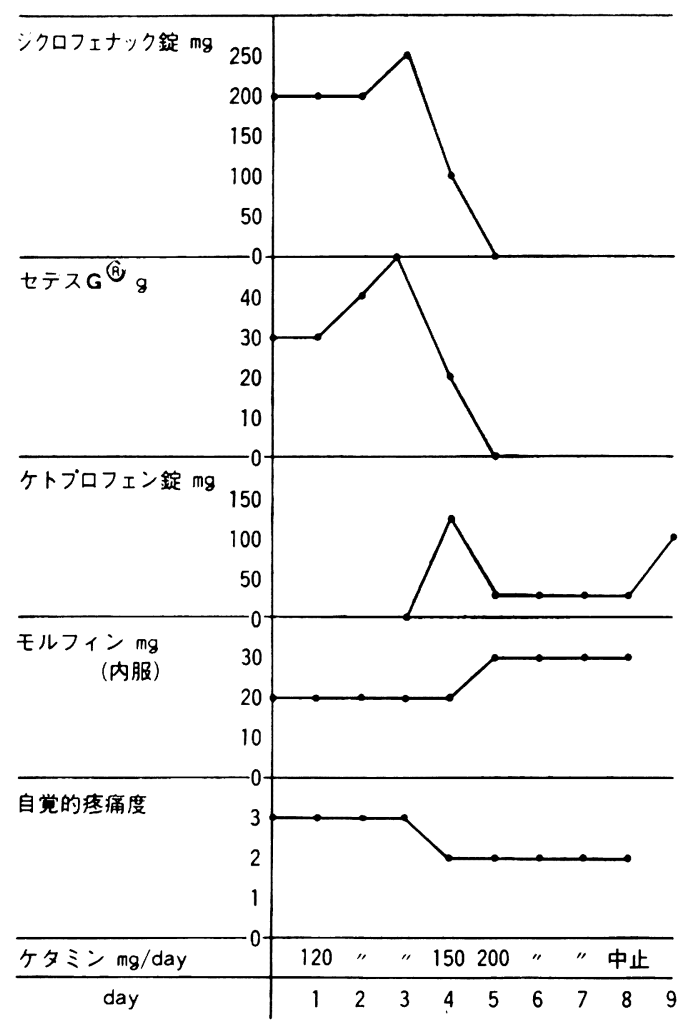

図 4 症例 4 : ケタ:ン使用中の併用鎮痛薬の 推移找上び自覚的疼痛度の変化

状態となった。40日間の投与期間中, ほぼ無痛に近い効 果が得られた。ケタミン增量後, 一時不眠を訴えたため diazepam $5 \mathrm{mg}$ を投与した。

\section{表 3}

\begin{tabular}{|c|c|c|c|c|}
\hline No. & $\begin{array}{c}\text { 使用日数 } \\
\text { (日) }\end{array}$ & $\begin{array}{l}\text { 平均使用量 } \\
\text { (mg/day) }\end{array}$ & 副作用 & 効果判定 \\
\hline 1 & 15 & 136 & 皮下硬結 & 著効 \\
\hline 2 & 3 & 140 & 眠気, 倦䓌感 & 無効 \\
\hline 3 & 40 & 242 & 皮下硬結 & 著効 \\
\hline 4 & 7 & 158 & 倊怠感, 皮下硬結 & 有効 \\
\hline 5 & 16 & 172 & 皮下硬結 & 有効 \\
\hline
\end{tabular}

5 症例のケタミン持続皮下注の期間, 1 日平均使用 量, 副作用, 効果判定

症例 4（図 4) 下顎歯肉腫瘍再発例で, 顎下部より側 頭部にかけての持続性疼痛を訴える82歳の女性. モルフ ィン $30 \mathrm{mg}$, 多量の鎮痛剂によっても十分な除痛効果が 得られなかった. $5 \mathrm{mg} /$ 時のケタミン投与を開始したが, 効果なく 4 日目より $7.5 \mathrm{mg} /$ 時に増量したところ, 疼痛 は緩和し, 疼痛度は 2 と判定したが, 自覚的には疼痛が 半減しているとのことであった。

一方, 全身倦忠感が徐々に增強してきたため, ケタミ ンの投与を 7 日間で中止した。中止後, 僚吝感は消失し たが, 再度激痛が出現した。

症例 5 (図 5) 舌腫瘍再発例で下顎部から後頸部に持 続性疼痛を有する51歳の男性. ケタミン投与開始 2 日目 より $7.5 \mathrm{mg} /$ 時で永服されるまでの 16 日間投与した。疼 痛度は 3 であったが, 自覚的には疼痛が半減し, 1 日数 時間の無痛が得られた。苦悶状表情は消失し, 筆談によ る痛みの訴えの回数も減少した。

表 3 に 5 症例のケタミン持続皮下注入期間，1 日平均 使用量, 副作用ならびに効果判定を示した。 


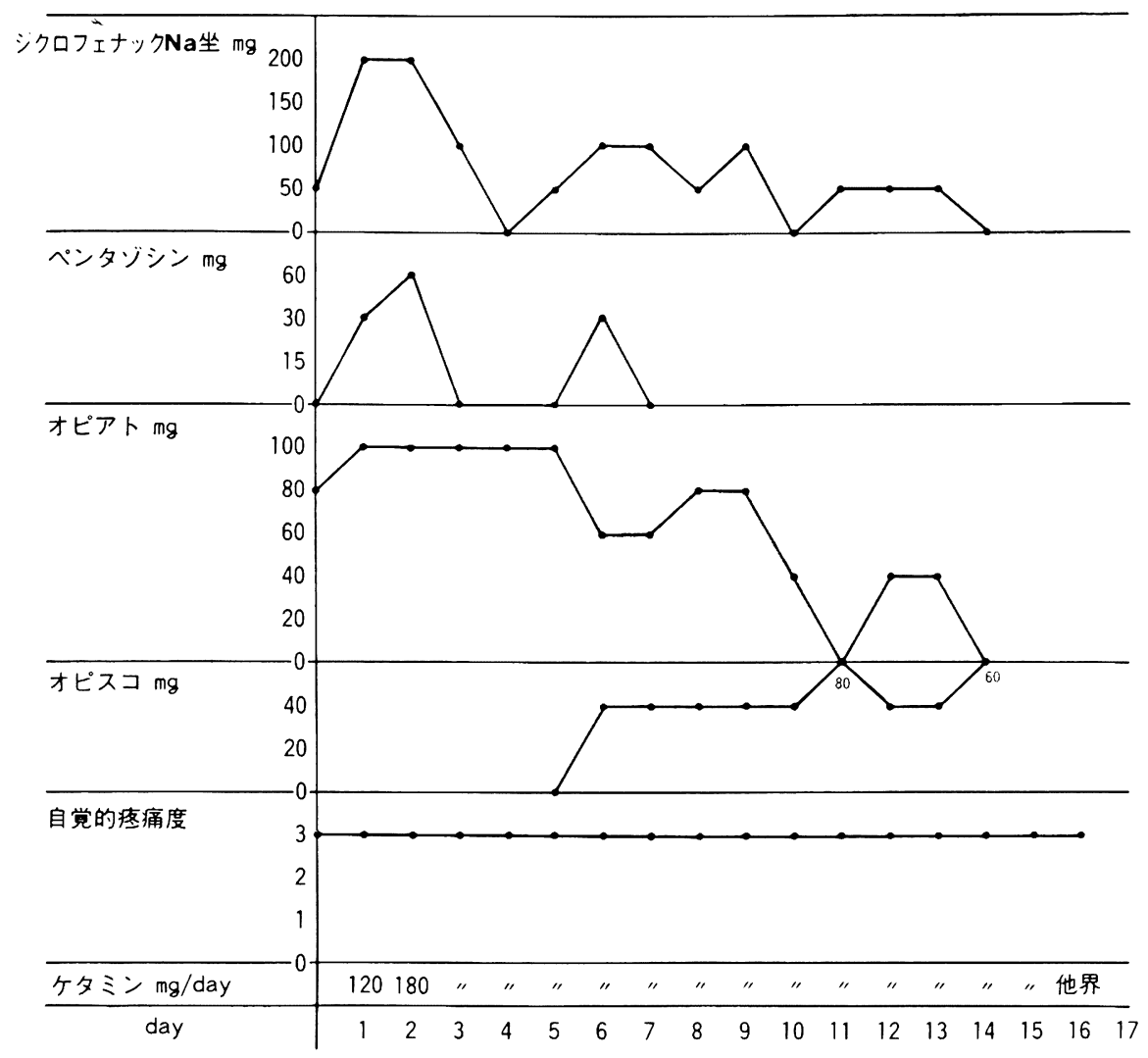

図 5 症例 5 : ケタ シン使用中の併用鎮痛薬の推移扣上び自覚的疼痛度の変化

考察

英国のホスピスでは, 癌性疼痛に対して麻薬の持続皮 下投与が 以前より行われてきたと野田ら²)は述べてい る.

本法の特徵は, 手技が簡単で持続注入器があれば誰に でも行えること，意識を清明に保ちながら持続的な除痛 効果が得られること，重篤な副作用が認められないこ と，患者の日常生活を制約しないこと，などの利点があ る。頭頸部領域の癌性疼痛に対寸る鎮痛法は，十分な除 痛効果が得られるとともに, 意識を清明に保ちつつ, 日 常行動（歩行，排尿，排便など）を制約しないことが望 まれる，今回われわれが本法を試みたのは，この条件が 満たされると考えたからである。 5 症例は何れも末期癌 であったが，2 例に著効が認められ，また特記すべき副 作用もなく本法の有用性が示唆された。刺入点の皮下硬 結が多くみられたが一過性であった。大島ら口も皮成へ の為害性は認めなかったと述べている.

ケタミンの鎮痛作用と麻酔作用の作用発現血中濃度は おのおの, $150 \mathrm{ng} / \mathrm{m} l, 650 \mathrm{ng} / \mathrm{ml}$ と報告されている3).
この大きな濃度差は，麻醉作用を示さず鎮痛作用が得ら れることを示唆している。

副作用として症例 2 と 4 において $7.5 \mathrm{mg}$ /時で眠気や 倦总感が出現したが, 症例 3 では $12.5 \mathrm{mg} /$ 時で何ら訴 えがなく，個人差がみられた。したがって各症例ごとに 投与量を設定する必要があると思われた。

疼痛の増悪, 緩解には, 心理的因子が大きく影響する ことが知られている。頭頸部領域では, 顔貌の醜形, 咀 嚼障害, 嚥下障害などの審美的, 機能的障害などを伴う ことが多く，患者は痛及と不安の中で自閉孤立に陥りや すい，このような心理的負担の軽減も疼痛治療上重要で あり, 患者の精神的援護はもちろん, 補助として向精神 薬の併用も必要と思われる。 しかし, 催眠, 鎮静, 抗不 安作用をもつバルビタールやジアゼパムは，長期連用で 耐性と依存を認めるため, 注意が必要である. その点, ヒドロキシジン, ディフュンヒドラジンが有效かつ安全 である4).

本法はいくつかの検討すべき問題を残してはいるが, 手技が簡単で, 患者の行動制約がなく安全性が高く, 特 別の看護も必要とせずに, 鎮痛が得られるといら理由か ら, 頭頸部の癌性疼痛の除痛法として有用と考兄られる. 
結

語

癌末期の癌性疼痛に対して, ケタミンの持続皮下注入 法による除痛を試みた。

1. 5 例中 2 例に著効, 2 例に有効, 1 例が無効であっ た。

2. 副作用として皮下硬結，眠気，倦总感がみられた が，特に重篤なものはなかった。

3. ケタミン投与中の 患者の意識レベルは, 常に清明 であり，日常の行動にも支障は認められなかった。

本諭文の要旨は, 昭和 61 年 7 月 25 日第 12 回日本口腔外 科学会北日本地方会（盛岡）に抋いて発表した。

\section{引用文 献}

1）大島英治，浦部伸方：癌性疼痛に対するヶ夕: ンの持続皮下注入法。臨床麻酔 10：531-532 1986.

2) 野田淳子, 梅田信一郎：ブプレノルフィンの持 続皮下注入による癌性疼痛の治療。医学のあゆ み 132: 450-451 1985.

3) Nimmo W.S. and Clements, J.A.: Ketamine on demand for postoperative analgesia. Anaesthesia 36: 8261981.

4) Murphy T.M.: Treatment of chronic pain. Anaesthesia. Miller R.D. (Ed.) Churchill Livingstone, New York, 1986, p 2077-2109. 